\title{
Evaluation of Certified Teachers
}

\author{
Siti Rochanah*, Munawir \\ Doctor Candidate \\ Universitas Muhammadiyah Surakarta \\ Surakarta, Indonesia \\ *ana_pwt@yahoo.co.id
}

\author{
Kumaidi \\ Department of Psychology \\ Universitas Muhammadiyah Surakarta \\ Surakarta, Indonesia \\ kuma_426@yahoo.com
}

\author{
Waston, Furqan, Deddy Ramdhani \\ Department of Islamic Education \\ Universitas Muhammadiyah Surakarta \\ Surakarta, Indonesia \\ Waston.ums@gmail.com, furqan_daeng@yahoo.com,deddyramdhani@uinmataram.ac.id
}

\begin{abstract}
This evaluation research intends to define the achievement of certified teachers in Senior High Schools (HS). The first variable is compiling lesson plans, the second is performing learning in class, the third is attending evaluations, the fourth is student guidance. The research found that the instrument model measures the evaluation of certified teachers, teacher performance meets the standards, low, medium, or high categories. This study used qualitative and quantitative methods, a sample of 86 certified teachers. The instrument consisted of 80 items designed from the previous prototype, namely the teacher performance evaluation instrument; interview guide, and questionnaire. Data analysis by arranging data through patterns, basic descriptions, and data categories was tested using Mardaphi statistical analysis techniques. Furthermore, the preparation of the instrument refers to the Borg \& Gall application, namely the stages of preliminary study, formulating requirements, formulating model formulation, and implementation. This study found an evaluation instrument capable of measuring teacher performance accurately in carrying out learning. The conclusion from the first research variable is that the teacher's performance in compiling the lesson plans is category as good. Second, the implementation of learning in the classroom is a category as good, the third evaluations are in a good category, the fourth is guiding students in the medium category because the teacher's performance is not optimal, and the opportunity to get scholarships to continue studies is however inadequate.
\end{abstract}

Keywords-evaluation, teacher performance, teacher certification

\section{INTRODUCTION}

Efforts to improve the quality of education have been and continue to be carried out by the government through various policies. Two policies regarding the quality of teaching personnel in Indonesia are policies to increase the competency qualifications and professionalism of education, as well as policies to increase the welfare of teaching staff through certification [1]

This policy is very important, teachers are at the forefront of education, meet directly with students to transfer knowledge and technology, and educate positive values through coaching and modeling. In the hands of the teacher will produce quality students, academically, skills, emotional maturity, as well as morally and spiritually. This will produce future generations, ready to live in their time. Therefore, teachers must have high qualifications, competence, and dedication in carrying out their professional duties [1].

The opinion expressed by Kumaidi [2] has two root causes for the low quality of education (1) the learning process and (2) commitment to implementing learning. These two root causes come from the teacher element. This shows that improving the quality of education can be done by improving the learning process and the commitment of teachers to implementing learning.

The main personality that these teachers must have is the most reality requirement for educators, according to Parkey, enthusiastic teachers can be seen from (1) conveying very satisfying materials, (2) the material is related to the reality of life, (3) the learning process is running well and fun.

According to Darling [3], the spirit of teaching provides great benefits for a teacher to increase her potential and role as a teacher in implementing classroom learning. While the spirit of teaching can manifest the professional behavior of the teacher.

Law No. 14 of 2005 states that educator certificates are given to teachers who have met teacher professional standards. Teacher certification is the provision of teacher certificates to "proper" teachers so that it is hoped that their performance will increase, have an impact on improving the quality of learning and the quality of education sustainably, can improve the 
quality of education in Indonesia and the professionalism of teachers. Some of these opinions about teacher performance should be noted that a teacher is a professional educator whose job is to educate, teach, guide, direct, train, assess, and evaluate students in children's education from an early age through formal education, basic education, and secondary education.

Law No. 14 of 2005 concerning Teachers and Lecturers chapter IV article 20 (a) states that the standard of teacher work performance in carrying out professional duties, teachers are obliged to plan to learn, carry out a quality learning process, and assess and evaluate learning outcomes.

Measuring, assessing, monitoring the performance of professional teachers, a performance measurement device/instrument is needed. So far, what has happened is that teachers have been verified by supervisors when the professional allowance will be proposed. Professional allowances will be in vain if the performance teacher just wants to get allowances, not because of the professionalism and calling. Government Regulation No.16 of 2005 concerning National Education Standards, states that professional staff teachers are required to have S1 / D4 academic quality with a certificate from the Higher Education Institution.

Based on the focus of the study, a conceptual definition of teacher performance was obtained. In this study, teacher performance is conceptually defined as a teacher's presentation based on a quantitative measure of a job (learning activity) that can be completed efficiently, which is a manifestation of the understanding, ideas, concepts, and skills of a teacher within the scope of teacher performance.

Referring to the study of various theories about performance and performance evaluation as well as input from experts, the researcher in this study 4 (four) variables, i.e.: (1) compiling learning, planning (2) implementing classroom learning, (3) conducted an evaluation, (4) carries out the guidance of students. The design of the teacher performance appraisal model in learning at the high school education level is developed based on these four variables, all variables refer to the teacher's ability to carry out learning. The phenomenon occurs when certified teachers have not been able to show an increase in the quality of their professional competence. The performance of certified teachers in the Grobogan Regency High School is still not known with certainty. The lack of information on the achievement of certified teachers can be a parameter that the performance of certified teachers in Grobogan Regency is still not measured and has not been published.

The management for teachers carried out by the government through the provision of certification is quite good, on the other hand, there have not been many achievements shown by Islamic Education teachers in Grobogan Regency. To find out how far the professional competence of teachers has been improved, it is very necessary to have an in-depth evaluation and study, to create competent teachers, have high professionalism so that have an impact on improving the performance of certified teachers.
It can be said that the four core competencies of professional teachers have not been integrated into teacher performance as mandated by existing laws and regulations. Responding to this phenomenon, a system that can control teacher performance is needed. This study offers a continuous model of teacher performance evaluation, in the form of an instrument as a control system that can be carried out periodically to create a professional work culture.

Therefore, it is necessary to conduct a study of the performance of teachers who have received a diploma, to determine the level of teacher performance achievement so that the improvement of the quality of education can be monitored intensively [4].

Quality learning will lead students to achieve the expected competencies in an integrated manner between variables of attitude, knowledge, and skills. Performance evaluation will measure the extent to which the teacher has carried out duties in a professional manner following the standards set in the field of work, to motivate teachers to continue to improve their performance. This is relevant to Mardapi's opinion, efforts to improve teacher performance must be based on current conditions obtained through assessment activities [5].

Teacher performance in planning learning programs, the ability of teachers to carry out learning in class, carry out evaluations, and the ability of the teacher to carry out student guidance, if it is still in the low or moderate category, then it still needs to be seen what factors are the obstacles in developing learning programs that must be mastered before implementing learning in class.

Professional teachers who carry out learning always try and are guided by process standards, namely learning is held interactively, inspiring, fun, challenging, motivating students to actively participate and providing space to foster initiative, creativity, and independence according to their talents, interests, and development. physical and psychological students so that progress according to the stages that have been determined in the learning program. Teachers are required to provide follow-up treatment of the learning process to achieve certain competencies following the Minimum Completeness criteria, syllabus, and lesson plans that have been made by the teacher himself.

The same formulation was put forward by T.R. Mitchell that performance $=$ ability $\mathrm{x}$ motivation. To complete a certain task or job a person must have the ability to support the completion of the job and the motivation to carry it out. Both have strong and accurate relevance in producing effective performance, even superior performance.

Effective performance is the minimum level of acceptable work results, while superior performance is related to the level of achievement in work situations that exceed the required standards [6]. 


\section{METHODS}

This research is evaluative researchers conducted include the type of evaluative research on the performance of human resources. This study aims to carry out evaluations, assess teacher performance and describe data in the form of information and statements about the performance of certified teachers.

This study used the qualitative method also called an interpretative method because the data from research outcomes widely concerned with the analysis of data found in the field [7], Qualitative research purpose is an analysis process designing descriptive data, planned and verbal score and response to recognizing analysis objects.

The quantitative approach uses data collection techniques in the form of questionnaires and observations with a questionnaire instrument from the teacher achievement appraisal rubric.

Moreover, to check and improve the correctness of the data from the questionnaire, qualitative data were collected using interview procedures and document study. The instrument application consists of 80 items, assigned concerning Borg \& Gall [8], within four steps, 1). In the preliminary study step, a literature review is carried out, obtaining theoretical and empirical performance in learning, teacher assessment models, and focus group discussions with supervisors, principals of HS 2). The needs identification step is carried out by arranging instrument items. Then the instruments continued interpreted through focus group discussions by experts to get instruments that could be used to appraise teacher representation in learning 3 ). In the preparation step of the teacher performance appraisal model of learning, input from the evaluator is used as a basis for developing an assessment model. 4). The implementation step is an instrument that has met the requirements used to assess teacher performance in learning at the HS Grobogan Regency. The assessment was carried out to teachers who taught the Islamic Education subject and as many as 86 . The performance appraisal model for instrument-certified teachers consists of 80 items with details of variable 1 as many as 20 items, variable 2, 20 items, variable 3, 20 items and variable 4, 20 items too. From the results of the questionnaire data, the results of the performance categories of certified teachers in the Grobogan Regency will be obtained using calculations from Mardapi [5], comparing the results of the assessment with the categories.

The next step is to determine the category of teacher achievement in learning based on the transformed scores that have been obtained. The calculation is done with the excel program. The determination of categories is carried out by steps based on calculations from [5], as follows : (1) Determine the maximum score by multiplying 4 (biggest score) by the number of items, (2) Determining the minimum score, multiplying by the number of items, (3) Determine the average ideal score $($ ) with the formula $==\mathrm{X}$ (ideal maximum score + ideal minimum score), (4) Determine the ideal standard deviation $((\mathrm{SBx})$ with the formula $\mathrm{SBx}=\mathrm{x}$ (Maximum ideal score - ideal minimum score), (5) Comparing the results of the assessment (scores obtained from the results of the teacher learning performance assessment model) with categories. The provisions of the categories that have been determined are as follows:

$$
\begin{aligned}
& X \geq \bar{X}+1 . S B_{x}: \text { Very high (1) } \\
& \bar{X}+1 . S B_{x}>X \geq \bar{X}: \text { High (2) } \\
& \bar{X}>X \geq \bar{X}-1 . S B_{x}: \text { middle (3) } \\
& X<\bar{X}-1 . S B_{x}: \text { low (4) }
\end{aligned}
$$

(6) After obtaining the criteria, then the number of frequencies was determined to find out how many students gave the categories Very High, High, Medium, Low, Very Low in each of the assessed variables.

\section{A. Figures and Tables}

1) Compiling learning planning: The results of the study

\begin{tabular}{|c|c|c|c|c|c|}
\hline No & $\begin{array}{c}\text { Interval } \\
\text { Score }\end{array}$ & Category & Frequency & Percentage & $\begin{array}{c}\text { Score } \\
\text { average }\end{array}$ \\
\hline 1 & $X>73.76$ & $\begin{array}{l}\text { Very } \\
\text { High }\end{array}$ & 4 & $4.65 \%$ & \multirow{4}{*}{$\begin{array}{l}60,99 \\
\text { (Medium) }\end{array}$} \\
\hline 2 & $\begin{array}{l}65.25<X< \\
73.76\end{array}$ & High & 23 & $26.74 \%$ & \\
\hline 3 & $\begin{array}{l}56.73<X< \\
65.25\end{array}$ & $\begin{array}{l}\text { Mediu } \\
\mathrm{m}\end{array}$ & 32 & $37.21 \%$ & \\
\hline 4 & $\begin{array}{l}48.22<X< \\
56.73\end{array}$ & Low & 27 & $31,40 \%$ & \\
\hline Total & & & 86 & $100 . \%$ & \\
\hline
\end{tabular}
declared that eighty-six teachers increasingly understood how to prepare and design learning as a whole.

TABLE I. COMPILING LEARNING PlanNING

Based on tables 1 it can be seen that the performance of the learning program organizers of 86 teachers is in the very high category $4(4.65 \%)$, high category $23(26.74 \%)$ medium category $32(37.21 \%)$, and low $27(31,40 \%)$.

Tables 1 above HS the teacher's score in the good category, some variables are very good, according to Mardapi scale. In other words, the teachers have been able to set goals carefully and formulate the steps for learning activities well. In making lesson plans, teachers understand the components that must be in the lesson plan. However, there are several variables in learning, planning that need to be improved, namely intending specific use of learning methods, learning resources, and media used in knowledge. Besides, these teachers have not made lesson plans according to student characteristics, so there is only one brand of a lesson plan for all students where each student has different styles. The learning materials or assignments used are the same for all children's characteristics, not differentiated for children with low, medium, or high abilities. 
2) Implement learning in the classroom: In this variable, all teachers have a good performance in managing classes during learning.

TABLE II. IMPLEMENT LEARNING IN THE CLASSROOM

\begin{tabular}{|c|c|c|c|c|c|}
\hline No & $\begin{array}{c}\text { Interval } \\
\text { Score }\end{array}$ & Category & Frequency & Percentage & $\begin{array}{c}\text { Score } \\
\text { average }\end{array}$ \\
\hline 1 & $X \geq 69.06$ & $\begin{array}{l}\text { Very } \\
\text { High }\end{array}$ & 1 & $1.16 \%$ & \multirow{4}{*}{$\begin{array}{l}59,66 \\
\text { (Medium) }\end{array}$} \\
\hline 2 & $\begin{array}{l}62.79 \leq X \\
<69.06\end{array}$ & High & 35 & $40.70 \%$ & \\
\hline 3 & $\begin{array}{l}56.53 \leq X \\
<62.79\end{array}$ & Medium & 25 & $29.07 \%$ & \\
\hline 4 & $\begin{array}{l}50.26 \leq X \\
<56.53\end{array}$ & Low & 25 & $29.07 \%$ & \\
\hline & Total & & 86 & $100.00 \%$ & \\
\hline
\end{tabular}

Based on Table 2 above, it can be seen, 86 respondents stated that most of the respondents' performance of teachers in implementing learning (management) in the classroom was in very high category $1(1.16 \%)$. There are $35(40.70 \%)$ high categories, $25(29.07 \%)$ medium categories, 25 (29.07\%) and low categories

Tables 2 above shows that the teacher's score on the variable of implementing learning in the classroom is in a good category and any sub-variables are very good. The teacher's performance, among others, is shown by the attitude of all teachers who always try to respect students, develop a learning culture in the classroom with various activities so that children do not get bored of following class lessons. The teacher uses polite speech in delivering the subject matter so that students are interested and like the teacher. Because the current curriculum is the 2013 curriculum, learning is not always brought out in the classroom, the teacher also invites out of the classroom when learning gets a place. Students are asked to observe their surroundings, discuss with friends. With the learning method outside of school, students are not bored to learn so that they can understand the lesson well.

3) Variable 3. Conducting evaluations: At the stage of carrying out the evaluation, based on the results of the principal's rubric, all teachers had a good performance.

TABLE III. CONDUCTING EVALUATION

\begin{tabular}{|c|c|c|c|c|c|}
\hline No & $\begin{array}{c}\text { Interval } \\
\text { Score }\end{array}$ & Cate gory & Frequency & Percentage & $\begin{array}{c}\text { Score } \\
\text { average }\end{array}$ \\
\hline 1 & $X \geq 71.69$ & $\begin{array}{l}\text { Very } \\
\text { High }\end{array}$ & 2 & $2.33 \%$ & \multirow{4}{*}{$\begin{array}{l}58,88 \\
\text { (Medium) }\end{array}$} \\
\hline 2 & $\begin{array}{l}63.15 \leq X< \\
71.69\end{array}$ & High & 34 & $39.53 \%$ & \\
\hline 3 & $\begin{array}{l}54.61 \leq X< \\
63.15\end{array}$ & $\begin{array}{l}\text { Mediu } \\
\mathrm{m}\end{array}$ & 24 & $27.91 \%$ & \\
\hline 4 & $\begin{array}{l}46.07 \leq X< \\
54.61\end{array}$ & Low & 26 & $30,24 \%$ & \\
\hline \multicolumn{3}{|c|}{ Total } & 86 & $100 \%$ & \\
\hline
\end{tabular}

Based on the table 3 above, it can be seen from 86 respondents that it is known that most of the respondents interpreted the teacher's performance in evaluating to be in very high category $2(2.33 \%)$. There are 34 (39.53\%) high categories, $24(27.91 \%)$ medium categories, 17 (19.77\%) low categories and $9(10.47 \%)$ very low categories. Tables 3 above shows that the scores of the teachers on the variable of carrying out the evaluation were in a good category and some of the sub-variables were very good. But based on the opinions of some students, there are still teachers who always order their students to work on the questions while only providing a few explanations. Some teachers speak too fast in explaining the subject matter so that students still do not understand the subject matter. In learning, the teacher uses a discussion system in both HS and large groups. By creating a group system, students will interact with their friends. Students practice, learn to cooperate with their friends.

4) Variable implement guiding students: In the Variable of guiding students, teachers have a good performance, medium category.

TABLE IV. GUIDING STUDENTS

\begin{tabular}{|c|c|c|c|c|c|}
\hline No & $\begin{array}{c}\text { Interval } \\
\text { Score } \\
\end{array}$ & Category & Frequency & Percentage & \begin{tabular}{|c|}
$\begin{array}{c}\text { Score } \\
\text { average }\end{array}$ \\
\end{tabular} \\
\hline 1 & $X \geq 46.92$ & $\begin{array}{l}\text { Very } \\
\text { High }\end{array}$ & 0 & $0.00 \%$ & \multirow{4}{*}{$\left(\begin{array}{c}32,21 \\
\text { (Medum })\end{array}\right.$} \\
\hline 2 & $\begin{array}{l}37.11 \leq X< \\
46.92\end{array}$ & High & 36 & $41.86 \%$ & \\
\hline 3 & $\begin{array}{l}27.31 \leq \mathrm{X}< \\
37.11\end{array}$ & Medium & 16 & $18.60 \%$ & \\
\hline 4 & $\begin{array}{l}17.50 \leq X< \\
27.31\end{array}$ & Low & 34 & $39,53 \%$ & \\
\hline \multicolumn{3}{|c|}{ Total } & 86 & $100.00 \%$ & \\
\hline
\end{tabular}

Based on Table 4 above, it can be seen from 86 respondents that it is known that most of the respondents interpreted the teacher's performance in implementing student guidance as $0 \%$ in the very high category. There were $36(41.86 \%)$ high categories, $16(18.60 \%)$ medium categories, 34 (39,53\%) and low categories

Tables 4 above shows that the scores of the teachers on the variable of carrying out the guidance of students are in the medium category. Likewise, moreover, based on the observations of the vice-principal, all teachers have a good performance. That good representation of this teacher is obtained from the habits of teachers who always reflect on their teaching and also notes that are maintained by the teacher such as teaching journals, student attendance. However, even though teacher performance was stated to be moderate, based on the outcomes of independent with teachers and school principals, there were still some HS there were still some shortcomings.

Namely the shortage of communication between teachers and parents or guardians of students, in terms of the learning process, there are still teachers who have not contributed either to the name of the school itself or local agencies such as high achieving. Also teachers are still not showing their professional 
development, besides the observations of the vice-principal, all teachers have a good performance.

\section{FINDINGS AND DISCUSSION}

\section{A. Findings}

This study found an evaluation model (performance appraisal model) for certified teachers in learning.

As a prototype, the assessment model (instrument) can provide accurate and complete information about the performance of certified teachers in implementing learning in schools. A review of various kinds of literature, earlier research, and a combination of supporting findings form the basis for the development of this performance appraisal model.

The final result of this stage is to find a prototype of the assessment model as the initial design of the certified teacher performance appraisal instrument.

Based on a study of various performance evaluation theories as well as input from experts in their fields, the performance evaluation of certified teachers by researchers refers to four variables (1) Compiling Learning Planning (2) Carrying out classroom learning (3) Carrying out evaluation, (4) guiding student

\section{B. Discussion}

The study of various works of literature, researches, and a combination of the previous supporting findings form the basis for the preparation of this evaluation research.

The findings of this evaluation research have similarities and support the research conducted by Tethys Arsynta in 2015 entitled "The Performance of Professionally Certified Teachers in Learning at State Vocational High Schools in Magelang City". The results of his research assumed that the realization of professionally certified teachers in learning planning was categorized as well [9].

The findings of this study are also the same as the results of research conducted by Suyanti [10] regarding the evaluation of teacher performance in junior high schools as pilot international schools in the city of Yogyakarta. Saint's research results concluded that personality competence, pedagogic competence, and social competence are categorized as well. According to Setyowati \& Sulasmono [11], the teaching performance of certified class $\mathrm{V}$ teachers in the Assisted Area 2 Parakan District in the field of Learning Planning and Implementation is in the good and a good category.

The research findings that the author produces show a slight difference with the research conducted by Tethys A, in his research it concludes that the performance of professionally certified teachers in the implementation of learning with class management sub-components is only categorized as sufficient, the sub-component of the use of learning methods is also categorized as adequate, and the sub-component of the use of media and learning resources is also categorized as sufficient.
Meanwhile, the performance of certified teachers of the Mango Cluster of the self-development component is in poor criteria [9]. The results of Suyanti's research also concluded that the professional competence obtained by the teacher was only categorized as sufficient.

Furthermore, Kurniawan [12] research entitled "Implementation of Teacher Certification Policies in the Context of Increasing Teacher Professionalism in the City of Yogyakarta" concludes that when viewed in terms of the impact of certification policies, there has been no significant increase in teacher professionalism, "Professional Attitude-al" also shows the performance of certified teachers (professional teachers) is not better than the performance of teachers before being certified. Even teacher performance has decreased because they feel they are no longer being assessed, and there are no sanctions after obtaining certification. Therefore, it is necessary to evaluate the performance of teachers who have been certified on an ongoing basis.

As for the teacher certification policy, Khodijah's research [13] on the performance of post-certification Madrasah Teachers and Islamic Education (PAI) Teachers in South Sumatra, shows that there is no difference in teacher performance after receiving the professional allowance in the variables of (1) lesson plans, implementation, and assessment; (2) Between those living in rural areas and urban areas; and (3) between those who passed through the portfolio and those who went through the PLPG. In other words, the performance of certified teachers is still below the minimum standard of performance.

\section{CONCLUSIONS}

Based on the findings of the discussion and research findings Evaluation of Certified Teacher as defined above, it can be concluded as follows:

- The teacher submitting judgment model in learning was developed including to Borg \& Gall, specifically: there are four stages. The first stage is a preliminary study, the second stage is the identification of needs, the third stage is the preparation of the instrument model, the fourth stage is the implementation of the results instrument.

- This study found an evaluation model, as a prototype, (an instrument) that can provide accurate and complete information about the instrument of certified teachers. The construct instrument is arranged based on 4 variables, i.e.: compiling a lesson plan of 20 items, carry out of learning 20 items, carry out of evaluation 20 items, carry out of student guidance 20 items.

- This research can be concluded that four things are according to the variable research that has done expressed, i.e.: The performance of certified teachers in preparing lesson designs is in a good category; in carrying out evaluations is in a good category; in 
carrying out the guidance students is in the medium category. This is because teachers' accomplishment is still un optimal in self-development, shortage of professional guidance, and included timeliness to obtain scholarships for more faraway studies. Based on the findings of research on performance evaluation of certified teachers, there is a suggestion: that teachers are more active in competing in professional progression and enhancement such as seminars, workshops. So that teachers can develop and improve their educational profession. so that all teachers can contribute to accomplishment.

\section{ACKNOWLEDGMENT}

We are very grateful to the management of the High School MGMP (Subject Teacher Meeting) in Grobogan District, Central Java, Indonesia for accepting us to conduct research on the evaluation of certified teachers.

\section{REFERENCES}

[1] Kunandar, Professional Teachers: Implementation of Education Unit Level Curriculum (KTSP) and preparation for teacher certification. Jakarta: Raja Grafindo Persada, 2007.

[2] Kumaidi, "Mathematics Education Development: The Vision of a Class Assessment Specialist," Papers of the National Conference on
Mathematics Research and Learning III, Univrsitas Muhammadiyah Surakarta, 2018.

[3] L. Darling, Evaliuating Teacher Effectiveness. Center for American Progrees, WaHSington, DC: H Street NM, 2010.

[4] Lubna, "Accuracy and Accountability of Performance Assessment of Islamic Religious Education Teachers, "Ulumuna, Journal of Islamic Studies, vol. 18, 2004.

[5] D. Mardapi, Technique for Preparation of Test and Non-Test Instruments. Yogyakarta: Mitra Cendekia Press, 2008.

[6] Rusman, Curriculum Management. Jakarta: Raja Grafindo Persada, 2009.

[7] S. Arikunto, Research Procedure A Practical Approach. Revised Edition. Jakarta: Rineka Cipta, 2013.

[8] W.R. Borg and M.D. Gall, Education Rechear: An Introduction (5 th.ed). New York : Logman, 1989.

[9] A.I. Kartomo and S. Slameto, "Performance Evaluation of Certified Teachers," Manage: Journal of Educational Management, vol. 3, no. 2, pp. 219-229, 2016.

[10] Suyanti, "Evaluation of Teacher Performance in Junior High Schools as Pilot Schools with International Standard in the City of Yogyakarta," 2009.

[11] T. Setyowati and B.S. Sulasmono, "Evaluation of Class V Teacher Teaching Performance Certified in the Development Area 2 Parakan District," Manage: Journal Educational Management, vol. 2, no. 1, pp. 86-98, 2015.

[12] B.D. Kurniawan, "Implementasi kebijakan sertifikasi guru dalam rangka meningkatkan profesionalitas guru di Kota Yogyakarta," Jurnal Studi Pemerintahan, vol. 2, no. 2, 2011.

[13] N. Khodijah, "Post-certification performance of madrasa teachers and Islamic religious education," 2013. 